\title{
ROMAŃSKI TYMPANON \\ KOŚCIOŁA PARAFIALNEGO W WYSOCICACH. GŁOS W DYSKUSJI
}

Rzeźbiarski wystrój romańskiego kościoła św. Mikołaja w Wysocicach miał szczęście do cenionych badaczy. Wprowadził go do literatury nestor polskiej historii sztuki, Władysław Łuszczkiewicz (1), a jako pierwszy obszerniej omówił Tadeusz Dobrowolski („Kościół św. Mikołaja” [1923] 8-11; „Kościół św. Mikołaja” [1931] 11-46; „Posąg Matki Boskiej” 37-49). Pisali o nim uczeni tej miary, co Tadeusz Dobrzeniecki („Maiestas Domini” 218 221, 225), Zygmunt Świechowski („Znaczenie najnowszego odkrycia” 273276; Budownictwo romańskie; Katalog architektury romańskiej 666-667) czy Michał Walicki (200), by wymienić tylko niektórych ${ }^{1}$. Zainteresowanie zabytkami wysocickimi osłabło w ostatniej ćwierci XX wieku, by odżyć u progu naszego stulecia za sprawą artykułów Katarzyny Hewner i Rafała Kalinowskiego. To głównie te najnowsze publikacje zachęciły mnie do sformułowania kilku polemicznych i uzupełniających uwag na temat tympanonu (il. 1), który, choć od dawna znany, w moim mniemaniu wciąż pozostaje niedoceniony.

Choć obiektem mojego zainteresowania będzie jedynie wspomniany tympanon, na początku warto doprecyzować, nieokreśloną dotąd jasno, stylistyczno-warsztatową relację między rzeźbioną figurą Maryi z Dzieciątkiem

Dr hab. Anna BŁAŻEJewsKa, prof. UMK - Uniwersytet Mikołaja Kopernika w Toruniu, Wydział Sztuk Pięknych, Katedra Historii Sztuki i Kultury; adres do korespondencji: ul. Bojarskiego 1, 87-100 Toruń; e-mail: abl@umk.pl; ORCID: https://orcid.org/0000-0003-2786-897X.

${ }^{1}$ Ze względu na ograniczenia w objętości niniejszego tekstu nie prezentuję pełnego, problemowo ujętego stanu badań. Wystrój rzeźbiarski wzmiankowany był w wielu opracowaniach syntetycznych, katalogowych czy przyczynkarskich, z których, poza omawianymi w tekście, wymienić należałoby jeszcze kilka: Kopera 414- 418; Furmankiewiczówna 19-20; Starzyński i Walicki 30; Dobrzeniecki, „Romański posążek” 114-115; Chrzanowski i Kornecki 35-36, 38; Mroczko 193-194. 
w szczycie elewacji korpusu a rzeźbami tympanonu ${ }^{2}$ (il. 2 i 3). Moim zdaniem nie ma wątpliwości, że rzeźbę w szczycie elewacji i w tympanonie kościoła w Wysocicach wykonał ten sam zespół. Świadczą o tym zarówno ogólne zbieżności formalno-stylistyczne, uwidaczniające się w syntetycznym kształtowaniu zaokrąglonych form poszczególnych członów rzeźb, jak też podobieństwa w szczegółach rzeźbiarskiego opracowania, zwłaszcza głów postaci: w kanciasto uformowanych podbródkach, podkówkowatych kształtach ust, rozciągniętych poprzecznie wypukłych gałkach ocznych obwiedzionych analogicznie podwójną linią powiek czy bardzo charakterystycznych, małych, ślimakowatych małżowinach usznych. Włosy Chrystusa ukazanego w tympanonie, jak i włosy umieszczonej na elewacji Madonny układają się na ramionach w tak samo szeroko rozłożone, grube, „wężowe" pasma (u Chrystusa rzeźbione bardziej detalicznie, z poprzecznymi nacięciami na całej ich powierzchni).

Tę warsztatową spójność wypada podkreślić szczególnie dlatego, że nieco

\footnotetext{
${ }^{2}$ Wynika to z tradycji badawczej; wzoru artystycznego dla Madonny z Dzieciątkiem szukano głównie w obrębie typu kompozycyjno-ikonograficznego, nie wśród podobnych stylowo rzeźb. Tak u Dobrowolskiego („Kościół św. Mikołaja” [1923] 11), który sugeruje wykonanie jej przez cystersa francuskiego działającego w Małopolsce; w późniejszej publikacji („Kościół św. Mikołaja" [1931] 41-42) zwrócił uwagę na jej podobieństwo do Madonny z portalu katedry w Bambergu i portalu północnego transeptu w katedrze w Reims (obie po 1200 r.), a także do Madonny z Gassicourt i posążka Maryi z Beaulieu; Furmankiewiczówna (20) widziała Madonnę w kręgu wpływów Madonn francuskich; Starzyński i Walicki (30) w rzeźbieniu figury Madonny szerokimi płaszczyznami dostrzegli formalne cechy rzeźby saskiej; Dobrzeniecki („Romański posążek" 114-115) zestawił Madonnę z Wysocic pod względem zbieżności formalnych z Madonną biskupa Imada z Paderborn, a jej układ kompozycyjny z Madonną z Dzieciątkiem w tympanonie fundacyjnym z kościoła św. Jerzego w Pradze; według Walickiego („Dekoracja architektury” 200) Madonna „nie ma w monumentalnym wyrazie bliskiego odpowiednika ani w materiale polskim, ani w europejskim”; Dobrowolski („Posąg Matki Boskiej” 40-41, 46-49) zrezygnowa z wcześniejszej hipotezy o Madonnie jako dziele francuskiego cystersa, podkreślił jej odmienność od Sedes Sapientiae we Włoszech, Niemczech, Francji i w Polsce. Za najbliższą kompozycyjnie i kostiumologicznie uznał Madonnę z Gnadenpforte w Bambergu, przy czym obie postrzegał jako refleks sztuki francuskiej. Gdy odkryto tympanon północny w kościele norbertanek $\mathrm{w}$ Strzelnie i dostrzeżono $\mathrm{w}$ nim podobieństwo do tympanonu w Wysocicach, badania rodowodu artystycznego obu grup rzeźbiarskich w Wysocicach jeszcze bardziej się rozeszły. Na to nałożyły się jeszcze domniemania o wtórnym zamontowaniu tego tympanonu w Wysocicach, pierwotnie przeznaczonego do kościoła w Imbramowicach (Dobrowolski, „Kościół św. Mikołaja” [1931] 35; Mroczko 193). Zaprzeczył temu Świechowski (,Znaczenie najnowszego" 276, przyp. 1), zwracając uwagę na jego dokładne osadzenie w ościeżach. Podobnie: Hewner, „Romański tympanon "111; Kalinowski 124-127. Kalinowski na podstawie oględzin struktury murów stwierdził, że oba zabytki - tympanon i Madonna z Dzieciątkiem - były wykonane in situ w trakcie wznoszenia budowli. W nowszych jednak publikacjach bezpośrednio nie podniesiono kwestii relacji warsztatowej tych dwóch zabytków.
} 
sztuczne rozdzielanie w literaturze rzeźb wysocickich na dwie grupy sprzyjało formułowaniu odmiennych opinii o ich klasie artystycznej; przy tym zdecydowanie gorzej oceniano tympanon. Zarówno określenia artykułowane przez starszą generację badaczy: „prymitywny, naiwny” i podobne ${ }^{3}$, jak i pojawiające się w najnowszym opracowaniu tego zabytku, u Rafała Kalinowskiego, odnoszące się do niektórych rzeźbionych partii tympanonu, uważam za niewłaściwe. Kalinowski, uznając tympanon za nieukończony, różnice w sposobie opracowania jego poszczególnych fragmentów traktował jednak nie jako wynik pozostawienia form rzeźbiarskich bez końcowego modelunku, lecz jako skutek zastąpienia mistrza przez „samouka”, który jakoby tympanon kończył (111-112, 114). To, co Kalinowski uznał np. za włosy Maryi „przypominające gładką, łysą masę”(111) (il. 4), może być raczej chustą okrywającą jej głowę; przykłady przedstawiania Maryi w połogu z odkrytą głową są dość rzadkie. Tympanon faktycznie nie został ukończony; widoczny jest brak niektórych szczegółów modelunku, jak np. graficznego zaznaczenia pofałdowań szat postaci klęczącej czy opracowania oczu u Maryi i Dzieciątka, włosów na głowie Dzieciątka. Dzięki jednak $\mathrm{w}$ miarę równomiernemu wydobywaniu form rzeźbiarskich z kamiennego bloku na całej powierzchni w trakcie procesu rzeźbienia brak wykończenia nie razi pod względem estetycznym, gdy ogarniamy wzrokiem całość dzieła. Dodajmy, że niektóre detale mogła pierwotnie dopełniać polichromia, podobnie jak domniemany wizerunek Gołębicy Ducha Świętego ${ }^{4}$, tak więc efekt całości mógł być niegdyś inny.

$\mathrm{Na}$ nie najlepszą ocenę jakości tympanonu wpływ miało także postrzeganie go z perspektywy związanego z nim warsztatowo, powszechnie uznanego za starszy, tympanonu strzelneńskiego, co sprzyjało sytuowaniu wysocickiego w roli jego naśladownictwa. To pozwoliło Świechowskiemu na opiniotwórcze stwierdzenie, że jak w Strzelnie, tak i w Wysocicach połączono ze sobą kilka wątków ideowych, tyle że już mechanicznie, dzięki pamięci wzrokowej kamieniarza. Sceptycyzm Świechowskiego w ocenie wartości programu obrazowego umocnił przekonanie, że tympanon z Wyso-

\footnotetext{
${ }^{3}$ Tak podają: Kopera 415 (rzeźba tympanonu dość nieudolna, w odróżnieniu od „pełnej nastroju i powagi” rzeźby Madonny z Dzieciątkiem); Dobrowolski, „Kościół św. Mikołaja” [1923] 11; „Kościół św. Mikołaja” [1931] 36-37 (całość tympanonu naiwna, prymitywna, „odsłaniająca duszę ludu, który od niedawna znalazł się w sferze kultury zachodnioeuropejskiej”, a figury ogólnikowo opracowane, o wadliwych proporcjach, grubych formach); „Posąg Matki Boskiej” 40-41 (tympanon „dość prymitywny”); Świechowski, „Znaczenie najnowszego” 275 (tympanon ten wykonano „bez kontroli teologicznej”).

${ }^{4}$ Kalinowski (109) dopatrzył się takich śladów.
} 
cic jest dziełem „wtórnym”. Wrażenie „wtórności” wysocickiego dzieła wzmocniły stosowane w literaturze przedmiotu określenia, że w Wysocicach jest „tron zamiast tęczy”, a „w miejsce księgi - chorągiew” (Świechowski, „Znaczenie najnowszego" 275; Soćko 111$)^{5}$. Ten ton pobrzmiewał też w stwierdzeniu: ,jak dalece w aspektach formy i treści może ulec przekształceniu wzór, który zainspirował fundatora" (Soćko 112).

W tym kontekście należy stwierdzić, że dostrzeżone przez badaczy podobieństwa stylistyczno-formalne do tympanonu w Strzelnie są niewątpliwie trafne (il. $1,2,5,6)^{6}$. Oba tympanony można uznać za dzieła tego samego zespołu kamieniarzy ${ }^{7}$ i przyznać czasowe pierwszeństwo strzelneńskiemu. Ich bliska relacja tym bardziej rzuca się w oczy, że z podobieństwem stylowym reliefów obu tympanonów zbiegło się zastosowanie kilku analogicznych motywów (układ szat Chrystusa, układ bestii pod stopami). Powiązanie warsztatowe tego dzieła (jak i figury Madonny z Dzieciątkiem, o czym należy pamiętać!) z tympanonem północnym w Strzelnie oczywiście stawia badacza wobec szerszego problemu - pochodzenia wysocicko-strzelneńskiego warsztatu - w związku z trudną do określenia bliższą genezą artystyczną tympanonu w Strzelnie. Teza Zygmunta Świechowskiego o jego nadreńskim lub nadreńsko-mozańskim rodowodzie („Studia nad rzeźbą” 107, 114), choć uzupełniana przez Adama Soćkę (109-112, 116-118) i Katarzynę Hewner („Próba identyfikacji” 16; „Romański tympanon” 111-112; „Tympanon w Wysocicach" 112-114, 124), podkreślającej pośredni wkład sztuki Wiligelma z Modeny, daje nam jedynie ogólny zarys tej genezy ${ }^{8}$. Chybiona

\footnotetext{
${ }^{5}$ Podkreślenie A.B.

${ }^{6}$ Niestety, tympanon północny w Strzelnie ma nieco zniszczoną powierzchnię, szczegółowa więc analiza porównawcza modelunku nie jest możliwa, ale do wymienianych w literaturze argumentów można jeszcze dodać: analogiczny układ szat na korpusie Chrystusa, podobnie wyobloną partię brzucha, włosy Chrystusa rozłożone w pasmach na ramionach, kształt ust i małżowin usznych, itp. W Wysocicach formy zdają się być jedynie nieco graniaste: ramiona, korpusy, nawet twarze (podbródki); fałdowania szat tworzą ostrzejsze „,"-kształtne załamania.

${ }^{7}$ Sugestia Hewner (,Romański tympanon” 109), by rozszerzyć analogie o inne strzelneńskie dekoracje rzeźbiarskie, zwłaszcza personifikacje na tamtejszych rzeźbionych kolumnach, nie wydaje się słuszna. Szczegóły fizjonomii personifikacji, na które się powołuje, są odmienne niż rzeźby w Wysocicach; inaczej, bardziej plastycznie, opracowano włosy, podbródki i usta. Podobny wydaje się schemat opracowywania szat - bryłowatych form, których powierzchnie urozmaicono rytmicznymi, graficznymi fałdkami, ale jest to dość powszechne w tym czasie.

${ }^{8}$ Soćko słusznie uznał, że tympanon z kaplicy św. Krzyża w Landsbergu (koło Halle) jest pod względem formalnym i ikonograficznym na tyle bliski strzelneńskiemu, że można uznać ten ostatni za „modyfikację modelu z Landsbergu”, może znanego autorom strzelneńskim z autopsji. Natomiast nie ma między nimi powiązań stylowych, a zatem nie ma ich też w odniesieniu do Wysocic. Sugestia Hewner, by w tympanonie strzelneńskim, jak i w innych tamtejszych rzeźbach
} 
wydaje się natomiast teza Kalinowskiego (124-127), by kamieniarzy pracujących w Wysocicach utożsamiać z warsztatem pochodzenia włoskiego działającym wcześniej w cysterskim kościele w Heiligenkreuz ${ }^{9}$; podane przez badacza - jako analogie - przykłady detali z Heiligenkreuz pozwalają raczej wykluczyć pokrewieństwo, niż je potwierdzić ${ }^{10}$. Podobieństwo dekoracji wspornika łuku tęczowego w prezbiterium w Wysocicach do kielichowych kapiteli w Heiligenkreuz - ważny argument dla tego badacza - w rzeczywistości nie istnieje. Wspornik w Wysocicach ma późnoromańską płaską dekorację lancetowo-guzową z motywem wstęgi, z drobnymi, wiotkimi listkami. Kapitele w Heiligenkreuz są wczesnogotyckie, o francuskiej genezie, z dynamicznie i sprężyście wystrzelającymi ze smukłego kielichowego

- a w konsekwencji także w wysocickich - widzieć dzieło szkoły (słabszych uczniów) Wiligelma z Modeny też ma słabe strony. Zauważone przez tę badaczkę podobieństwo między rzeźbami strzelneńskimi (na kolumnach i tympanonach) a dekoracją portalu i elewacji w alzackim Andlau (uznanych przez nią za dzieło uczniów Wiligelma) sprawiło, że uznała tożsamość warsztatu pracującego w Andlau i Strzelnie - zob. Hewner, „Próba identyfikacji” 16, 20-21, 26, 28, 36-37, 41. Gdy chodzi o Andlau, badaczka opierała się na starszej i skromnej literaturze przedmiotu. Boerner $(24,247-248$, przyp. 38-42, 45, 49) podaje literaturę odnośnie do romańskiej dekoracji architektury w Andlau. Warto zwrócić uwagę, że rzeźby strzelneńskie pod względem stylistyczno-warsztatowym prezentują się jako staranniejsze i efektowniejsze niż te w Andlau. Boerner (22, 24) określa je wręcz jako prymitywne, zarówno w Andlau, jak i w innych romańskich budowlach tego czasu w Alzacji: Gebweiler, Singolsheim i inne. Według niego rzeźby te wykonywali rzemieślnicy nawykli do dekoracji małoformatowych, np. wyrobów z kości słoniowej, a ich bezpośrednie powiązania z rzeźbami z San Silvestro w Nontanola budzą wątpliwości. Poza tymi wątpliwościami także spory dystans czasowy dzielący dzieła w Wysocicach od działalności Wiligelma i niewykraczające poza generalia podobieństwo form (bryłowate, przysadziste postaci z graficznie zaznaczanymi fałdami szat, podobne modelowanie włosów) sprawiają, że w odniesieniu do Wysocic ta teza nie przekonuje. Co do długotrwałych bezpośrednich italskich wpływów na rzeźbę Europy Środkowej, w tym Polski, sceptycznie wypowiedział się też Quirini-Popławski (47-51), sugerując, że uznawanie powszechności włoskich form rzeźbiarsko-architektonicznych w polskiej sztuce romańskiej to po części echo oddziaływań tzw. literatury neośredniowiecznej, kreującej nazbyt wyidealizowany, kulturotwórczy obraz Włoch północnych. Znamienne, że autor ten wśród inspiracji włoskich w rzeźbie romańskiej w Polsce nie wymienił ani realizacji strzelneńskich, ani - tym bardziej - wysocickich.

${ }^{9}$ Choć autor wspominał o tym jedynie w odniesieniu do detali architektonicznych obu kościołów (baz, głowic i dekoracji wspornika łuku tęczy), to biorąc pod uwagę, że dekoracja portalu i elewacji powstawała równocześnie z budowlą, mamy prawo mniemać, że ta proweniencja obejmuje także twórców wystroju rzeźbiarskiego.

${ }^{10}$ Romańska kolumienka we wnęce wschodniego skrzydła krużganków cysterskiego opactwa w Heiligenkreuz jest dziełem innego, starszego warsztatu niż wczesnogotycki kapitel kielichowy w północnym skrzydle tamtejszych krużganków; Kalinowski (125) użył przykładów z różnych etapów budowy wykonanych przez różne warsztaty. 
rdzenia pąkami (raczej typowe dla lat 1230/1240) ${ }^{11}$. Rozwikłanie kwestii proweniencji warsztatu pracującego $\mathrm{w}$ Wysocicach jest uzależnione od znacznie szerszych badań nad działalnością warsztatów w Europie środkowej i daleko przekracza ramy tego artykułu.

Niezależnie od trudności, jakie sprawia odszukanie rodowodu warsztatowego twórców tympanonu w Wysocicach, nie powinno się w nim upatrywać naśladownictwa układu kompozycyjnego czy tym bardziej programu tympanonu strzelneńskiego. Wysocicki zabytek prezentuje inny program i stosownie do niego dobrano środki wyrazu; w moim przekonaniu mniemanie o „wtórności” i słabej jakości artystycznej tego dzieła jest niesłuszne.

To, co Arnheim (109) nazywał „organizacją ogólną” pola obrazowego, w tympanonie zostało przez rzeźbiarza starannie przemyślane. Półkolisty obrys tympanonu $^{12}$ ujęto ramującą listwą, z łagodzącym jej uskok miękkim sfazowaniem. Dało to efekt płytkiej wnęki, w którą wprowadzono przedstawienia (il. 1). Zamknięcie tympanonu łukiem znalazło swoistą repetycję w zarysie dolnej strefy pola obrazowego, której górną granicę wyznacza linia siedziska Chrystusa, opadająca linia łoża Marii i linie ramion klęczących postaci po stronie przeciwnej. Wizualnie wyróżnia się ona mocno zagęszczoną kompozycją i nakładaniem się na siebie form. Powyżej kompozycja ulega rozrzedzeniu, w wielu miejscach przeziera tło, a reliefy w kilku miejscach śmiało wkraczają w strefę obramienia ${ }^{13}$, przy czym jedynie postać Chrystusa „podporządkowuje sobie" ową ramę całkowicie (jego głowa w całości ją przesłania). Tworząca oś kompozycji figura Chrystusa upozowana jest niemal idealnie symetrycznie, a ramiona Chrystusa i równoległy do nich układ ciał bestii pod jego stopami zakreślając linie powtarzających się parabol skierowanych ku górze stanowią kierunkową przeciwwagę dla łukowatej linii zamykającej od góry pole tympanonu i jej „powtórzenia” poniżej. Kumulacja przeciwstawnych kierunków na osi tympanonu, wyjątkowa symetria układu ciała Chrystusa, uchwytna wzrokowo dla widza jeszcze zanim ten rozpozna szczegóły przedstawienia, skupia uwagę na wizualno-semantycznym centrum. Na rzecz prymatu postaci Tronującego zdają się działać także

${ }^{11}$ Bliższe formalnie wysocickiej dekoracji roślinnej (pod względem fazy stylowej) wydają się niektóre z dekoracji detali cysterskich opactw małopolskich (np. Wąchock - wsporniki kapitularza i refektarza) czy nawet niektóre kapitele kolegiaty w Kościelcu Proszowickim. Odnośnie warsztatów i faz budowy Heiligenkreuz - oprócz wymienianej przez Kalinowskiego pracy Thome - zob. także Schwarz 36-37, gdzie zestawienie różnych stanowisk badaczy.

${ }^{12}$ Dla ścisłości - kształt jest niemal półkolisty; łuk jest nieznacznie obniżony.

${ }^{13}$ Szczególnie ciekawe relacje między obrazami a ich obramieniami obserwujemy w średniowiecznym malarstwie książkowym. 
przedstawienia po bokach, różne w charakterze, reprezentacyjne po lewej i bliższe narracyjnemu po prawej ${ }^{14}$, skontrastowane nie tylko z centralnym wyobrażeniem, ale i ze sobą; w reprezentacyjnym dominują linie pionowe (dokładniej: z lekkim ukośnym odchyleniem od pionu), a w narracyjnym linie niemal poziome, przy czym w obu przypadkach, choć w innym rytmie, wznoszą się one ku centrum ${ }^{15}$. Staranność w opracowaniu detali (oczywiście z wyjątkiem nieukończonych), zwłaszcza młodzieńczej twarzy Chrystusa (i1. 2) czy modelowanych także od strony niewidocznej dla widza twarzy postaci klęczących (il. 7), jak i łatwo dostrzegalna powtarzalność wypracowanych zasad szczegółów modelunku zdradza doświadczonego, wprawnego rzeźbiarza i solidne wykonawstwo.

Wypowiedzi badaczy ujawniły znaną prawidłowość, że nietypowość zabytku bywa nierzadko pewnym obciążeniem dla niego samego. W naszym przypadku przeświadczenie o słabej jakości tympanonu i jego naśladowczym charakterze, pobrzmiewające niejednokrotnie, spowodowało odnoszenie się z rezerwą także w kwestii spójności jego ideowego przekazu. Świechowski, widząc w nim tympanon fundacyjny, zbyt pochopnie uznał, że scena Bożego Narodzenia jest w nim po prostu zbędna („Znaczenie najnowszego” 275$)^{16}$, a Dobrzeniecki z kolei, dostrzegłszy związek między przedstawieniem Chrystusa triumfującego i sceną Narodzin, pominął zupełnie wizerunki klęczących postaci, jakby ich w tympanonie nie było („Maiestas Domini” 218221,225). Właściwie dopiero w najnowszych publikacjach: Katarzyny Hewner i Rafała Kalinowskiego podjęto próby rozwikłania sensu tympanonu jako całości złożonej $\mathrm{z}$ trzech przedstawień. Takie spojrzenie na dzieło jest niewątpliwie pożądane, natomiast $\mathrm{z}$ szeregiem poczynionych przez tych badaczy szczegółowych ustaleń trudno się zgodzić, a niektóre ich tezy domagają się uzupełnień.

Jedną z kwestii, która przewijała się w literaturze przedmiotu od dawna (choć niejako w tle) i jest aktualna do dziś, jest problem kwalifikowania (bądź nie) tego zabytku do tympanonów fundacyjnych. W opracowaniach dotyczących romańskich tympanonów fundacyjnych jako typu obiekt wyso-

${ }^{14}$ Wolfgang Kemp analizując średniowieczne systemy obrazowe dla tego typu przedstawień skrótowo ujętej sceny - używa określenia „Kurzszene” - zob. Kemp 46-48.

${ }^{15}$ Dominacja poziomych kierunków nie jest wyłącznie konsekwencją tego, że scena ukazuje postaci jako leżące. Znane są wyobrażenia Bożego Narodzenia, gdzie - zwłaszcza Maria spoczywała na łożu zakomponowanym bądź ukośnie, bądź ona sama pozostawała w pozycji na wpół siedzącej.

16 Niezbyt przychylnie wyraził się też i w późniejszej pracy: Świechowski, Katalog architektury 666 - ,zbitka kilku wątków ikonograficznych”. 
cicki nie był wymieniany, natomiast w wypowiedziach odnoszących się bezpośrednio do tytułowego zabytku niekiedy właśnie za taki jest uznawany; klęczące postaci utożsamia się wówczas z biskupem Iwonem Odrowążem i z jego krewnym - Jackiem Odrowążem lub nieznanym duchownym (Hewner, „Romański tympanon” 109,112; Kalinowski 116-117). Kalinowski nie wykluczył przy tym, że fundator został tu przedstawiony dwukrotnie jako biskup i jako diakon, co wydaje się jednak bardzo mało prawdopodobne. Ta niejasność wynika nie tylko z istniejących rozbieżności w identyfikacji wyobrażeń klęczących postaci. Pogłębia ją brak przedmiotu donacji (modelu kościoła), tak typowego dla wizerunków dedykacyjnych, jak też brak częstej w tympanonach fundacyjnych inskrypcji dedykacyjnej ${ }^{17}$. Ponadto tradycja przedstawień dedykacyjnych, sięgająca wizerunków wczesnochrześcijańskich, w apsydach kościołów preferowała symetrię, rozumianą albo kompozycyjnie - z centralnie umieszczonym Chrystusem (lub inną osobą obdarowywaną) i darczyńcami (nierzadko też z ich protektorami) po bo$\mathrm{kach}^{18}$, albo semantycznie, tj. ofiarujący-przyjmujący. Tympanony fundacyjne, szczególnie w Europie Środkowej, raczej zachowywały symetrię kompozycji ${ }^{19}$. Nieco większa swoboda $\mathrm{w}$ tym względzie pojawiła się w późniejszych tablicach fundacyjnych (Mrozowski, Polskie tablice, passim), choć i wówczas $w$ tympanonach preferowano tradycyjny modus ${ }^{20} . \mathrm{Z}$ tej perspektywy patrząc, w Wysocicach ów schemat obrazowy wydaje się naruszony; centralnemu przedstawieniu Chrystusa towarzyszą z jednej strony klęczące

${ }^{17}$ Nie jest to regułą, ale np. wśród tympanonów tego typu w Polsce jedynie tympanon z kościoła św. Prokopa nie miał inskrypcji. Nie można wprawdzie wykluczyć, że była ona w Wysocicach zamierzona i niezrealizowana, ale ramująca tympanon listwa wydaje się zbyt małej szerokości (niespełna $5 \mathrm{~cm}$ ), by móc wykuwać na jej powierzchni litery, zachowując choćby minimalny odstęp od krawędzi; w każdym razie byłoby to niezwykle uciążliwe.

${ }^{18}$ Oczywiście w zależności od liczby ofiarodawców i ich ewentualnych protektorów symetria mogła być zachwiana, zachowywano jednak reprezentacyjno-znakowy charakter wizerunków.

${ }^{19}$ Romańskie zabytki tego typu w Polsce to mniej lub bardziej symetryczne kompozycje: w kościele NMP na Piasku we Wrocławiu, w kościele Świętej Trójcy i rotundzie św. Prokopa w Strzelnie czy pochodzący z kościoła św. Michała na Ołbinie. Podobnie jest w wielu europejskich przykładach, by wymienić tylko niektóre: w katedrze w Bazylei (tzw. Galluspforte, ok. 1185 r.), w St. Ursanne czy w Singolsheim (wszystkie - Górna Nadrenia), u benedyktynów w Reinsdorf (Niemcy środkowe, z ok. 1200 r.), z benedyktyńskiego opactwa w Holzzelle (Niemcy środkowe, ok. 1200 r.), czy w San Clemente w Casauria (Abruzja) z XII wieku.

${ }^{20}$ Podobnie jak np. w Radłowie czy Lubiniu, ale i poza Polską - w XIII wieku: w Czechach na Hradczanach w kościele św. Jerzego czy w kaplicy zamkowej w Zvikov, u cysterek w Tišnov, w katedrze w Paryżu (porte rougue), czy w XIV-wiecznych przykładach: w południowym portalu katedry w Wormacji, w bawarskim Ettal, u franciszkanów w Wiedniu i inne. Na ten temat zob. także Walczak 146, 148-149. O zmianach, jakie zaszły w wizualnym upamiętnianiu aktu fundacji między romanizmem a późnym gotykiem zob. Mrozowski, „Gotyckie tablice” 55- 62. 
postaci - donatorzy (?), symbolizując akt fundacji, a $\mathrm{z}$ drugiej przedstawienie o charakterze narracyjnym ${ }^{21}$, z fundacją bynajmniej niezwiązane.

$\mathrm{W}$ takiej sytuacji mamy prawo mniemać, że w przypadku Wysocic albo popularny „schemat fundacyjny” został zmodyfikowany, gdyż taka zmiana miała dla twórcy jakieś znaczenie, albo sens tympanonu w ogóle nie ma związku z aktem fundacji. Poza starszymi propozycjami, by w klęczących postaciach widzieć niezwiązanych bezpośrednio z fundacją, św. Norberta (to w przypadku, gdy domniemywano jego pierwotne przeznaczenie dla norbertanek w Imbramowicach) ${ }^{22}$, św. Mikołaja czy św. Maurycego, sugerowała to drugie rozwiązanie Hewner („Tympanon w Wysocicach” 117-120), identyfikująca wizerunki klęczących postaci z Melchizedekiem i Abrahamem jako antytypami kapłaństwa Chrystusa (tym samym odwołała swoją starszą tezę, upatrującą w klęczącej postaci biskupa-fundatora Iwona Odrowąża: Hewner, „Romański tympanon” 109-110). Przedstawienia po prawej stronie tympanonu także określiła nieco odmiennie niż w starszej literaturze: za scenę Bożego Narodzenia uznała bowiem jedynie przedstawienie Dzieciątka i zwierząt nad żłobem, natomiast postać leżącą poniżej jako Złożenie do Grobu lub Chrystusa w Grobie („Romański tympanon” 108) (il. 1 i 4). Badaczka, zestawiając te przedstawienia z centralnie umieszczonym Chrystusem Tronującym, depczącym bestie, akcentowała, że ukazano Go tu w ciele chwalebnym, anagogicznie pojmowanym jako Pasja i Eucharystia. W konsekwencji całość uznała za prezentację dogmatu o Eucharystii (jako aktualizacji Wcielenia), nawiązującą do postanowień soboru laterańskiego z $1215 \mathrm{r}$. („Tympanon w Wysocicach” $110,115,119,124)^{23}$. Sens tympanonu odczytywała w wymiarze horyzontalnym - jako jedność dwóch natur Jezusa i dzieje zbawienia, i wertykalnym - jako egzegezę alegoryczną „znaków rzeczywistości transcendentalnej" (przejście ze śmierci do życia), co miało służyć dydaktyce kleru i miejscowej ludności („Tympanon w Wysocicach” 122123). O ile odczytana przez badaczkę myśl przewodnia może być, przynajmniej w części, trafna, to jednak rozpoznanie przez nią szeregu szczegółów nie jest właściwe. Słabą stroną argumentacji jest brak wskazania przez nią jakichkolwiek innych obrazowych przykładów podobnego łączenia tak zidentyfikowanych postaci czy scen. Mechizedek, o ile bywał przed-

${ }^{21}$ Lub tzw. Kurzszene - zob. przyp. 14 w niniejszym artykule.

${ }^{22}$ Kalinowski (109) uzasadnił jego przeznaczenie dla tego konkretnego portalu w Wysocicach, wskazując na jego dokładne dopasowanie do jego ościeży. Argumentem na rzecz „miejscowego" pochodzenia tympanonu jest też powiązana ściśle z jego warsztatem wykonawczym rzeźba Madonny z Dzieciątkiem w szczycie elewacji, o czym wyżej w niniejszym artykule.

${ }^{23}$ Podobnie w odniesieniu do unii hipostatycznej dwóch natur Jezusa (Kalinowski 115). 
stawiany w szatach biskupich, to jego identyfikację jako takiego umożliwiał kontekst (jako jeden z typów zestawionych z antytypem - Ofiarą Chrystusa) i inskrypcja ${ }^{24}$. W omawianym tympanonie takich „wskazówek” nie ma. Autorka nie wskazała też przykładów scen, w których przedstawiony byłby Melchizedek wespół z Abrahamem jako zakonnikiem (!) przynajmniej w zbliżonej relacji względem siebie (jeśli już nie względem Chrystusa). Co do przedstawionej sceny po przeciwnej stronie Chrystusa Tronującego badaczka nie dostrzegła, że ciało spoczywające poniżej Dzieciątka nie jest wcale „owinięte w śmiertelny całun” („Romański tympanon” 108). Postać ta, bez brody i wąsów, ma na sobie tunikę, półkoliście wyciętą pod szyją, poduszkę pod głową, a okryta jest w sposób analogiczny do licznych przedstawień Maryi leżącej w łożu czy to w scenach Zaśnięcia czy w połogu ${ }^{25}$. Brak też jakiegokolwiek uzasadnienia, jaką rolę w prezentacji dogmatu o unii hipostatycznej miałoby odgrywać ciało Chrystusa leżące ma marach. Z wywodu Autorki jedynie (bez wątpienia) słusznie wynika, że ciało Chrystusa w Grobie i Dzieciątko jest tym samym ciałem „ziemskim” („Tympanon w Wysocicach" 115). W żadnym wypadku nie negując swobody i nierzadko zaskakującej inwencyjności sztuki średniowiecznej (Berliner; Wirth 20), trzeba jednak stwierdzić, że brak wzorów/analogii obrazowych dla tak zestawionych postaci i scen (przy braku inskrypcji) rodzi poważne wątpliwości, czy tematy nieutrwalone wizualnie w typach obrazowych miałyby w praktyce jakąkolwiek szansę na rozpoznanie, a co za tym idzie - czy komunikowałyby treści, jakie - według badaczki - miały unaoczniać zarówno duchownym, jak i szerszej, lokalnej społeczności.

W innym kierunku podążył Rafał Kalinowski, który dostrzegł w przedstawieniach tympanonu bezpośredni związek z ufundowaniem kościoła przez biskupa Iwona Odrowąża. W obu wyobrażeniach w bocznych partiach tympanonu dopatrzył się przedstawień narracyjnych: odpowiednikiem sceny Bożego Narodzenia po lewej stronie - miałaby być scena ze zmierzającym na klęczkach ku Chrystusowi Iwo Odrowążem, fundatorem, a jednocześnie celebransem, w trakcie liturgii eucharystycznej (Ofiarowanie), wobec Trójcy Świętej, „ofiarującym coś, czego symbolem jest kielich” (116-117).

${ }^{24}$ Podane przez Autorkę przykłady przedstawień Melchizedeka na patenie z Weingarten czy z Saint Trudpert (zob. „Tympanon w Wysocicach” 117-118) właśnie dlatego mogły być przez nią poprawnie zidentyfikowane. Podobnym przykładem jest patena z Freiburga Bryzgowijskiego $\mathrm{z}$ ok. $1250 \mathrm{r}$.

${ }^{25}$ Co akurat nie zmienia faktu, że bizantyjskie obrazy Bożego Narodzenia mogą budzić skojarzenia ze złożeniem Chrystusa do Grobu ze względu na obecność w nich groty przypominającej czeluść otchłani - zob. Evdokimov 231-232. 
W trójdzielnym zamknięciu portalu, jak i w geście Chrystusa dostrzegł odniesienia do Trójcy Świętej (stwierdził, że tympanon dopełniał niezachowany malowany wizerunek Gołębicy powyżej Chrystusa), a jako temat główny przyjął trójjedyność Boga oraz unię hipostatyczną dwóch natur Jezusa (115 -116).

Żałować należy, że ani Hewner, ani Kalinowski nie znali wcześniejszej wypowiedzi Dobrzenieckiego dotyczącej tegoż tympanonu („Maiestas Domini” 218-221, 225). Otóż Autor ów przyjął, że zestawienie w Wysocicach wyobrażenia Chrystusa Triumfującego (deptanie zwierząt i trzymanie krzyża-znaku życia) ze sceną Bożego Narodzenia najpewniej nawiązuje do znanego w malarstwie książkowym przedstawienia, jakie umieszczano w bezpośrednim sąsiedztwie tekstu Prologu Ewangelii św. Jana, ergo - podobnie jak w przypadku iluminacji książkowej - wyobraża myśl o unii hipostatycznej dwóch natur Chrystusa. Dobrzeniecki wskazał na połączenie takich właśnie scen w Ewangeliarzu biskupa Bernwarda z Hildesheim (Hildesheim, Domschatz, Cod.18, fol.174) z ok. 1020 r., gdzie towarzyszą zdaniu: Verbum caro factum est. Podobnie połączenie tych dwóch motywów wyobraża Ewangeliarz z katedry w Bambergu (Bamberg, Staatsbibliothek, Msc. Bibl. 94) z ok. 1050 r. (il. 8), gdzie obrazy są nieco bardziej rozbudowane, a tekst Prologu włączony został w obręb miniatur. Andrea Worm (113-114) pisała, że ścisłe powiązanie obrazu i tekstu $\mathrm{w}$ przypadku tych dwu iluminacji Ewangeliarza Bamberskiego pozwala je określić jako egzegetyczny komentarz wizualny „ukazujący” zdania Prologu. Mamy prawo przypuszczać, że fakt pojawiania się takich dwóch skonfigurowanych ze sobą przedstawień oznacza, że mogły one być dla ówczesnych odbiorców wizualnie zrozumiałe i rozpoznawalne zarówno jako skojarzenie ze słowami Prologu, jak i w sensie teologicznym, jak widzieli to Dobrzeniecki, Hewner i Kalinowski z koncepcją dwóch natur Chrystusa. Zobrazowanie ważnego fragmentu tekstu Prologu w portalu kościoła mogło ponadto - jako czytelny dla wielu znak obrazowy - uobecniać moc tych mistycznie brzmiących słów, których „odmawianie uważano niejako za sacramentale udzielające specjalnego błogosławieństwa" (Klawek 278) ${ }^{26}$.

Co do przedstawienia w tympanonie Iwo Odrowąża jako fundatora $\mathrm{z}$ asystą, wobec obszernego omówienia tego zagadnienia przez Kalinowskiego, raczej nie może być wątpliwości ${ }^{27}$. Roman Michałowski („Święta moc fun-

${ }^{26}$ Zob. także: Bracha 29-30 - o znaczeniu słów Prologu jako magicznego zaklęcia przeciw demonom i niesprzyjającej pogodzie w średniowieczu.

${ }^{27}$ Zob. Kalinowski 106-109 - szerzej o dziejach fundacji kościoła i zmianie inwestora po śmierci biskupa Odrowąża w 1229 roku. 
datora" 12-13) w odniesieniu do życia religijnego w państwach niemieckich w XI-XII wieku podaje, że fundatorów kościołów i klasztorów traktowano (lokalnie) jak świętych. Czczono ich za życia, ale jeszcze bardziej po śmierci ${ }^{28}$. To mogłoby tłumaczyć nimb wyrzeźbiony wokół głowy biskupa, choć w wieku XIII obdarzanie nim osób nieuznanych za świętych było rzadkie (Ratkowska 337) ${ }^{29}$.

Czy należy jednak traktować przedstawienie klęczących duchownych jako procesję, czyli scenę narracyjną? Biskup unoszący kielich i towarzyszący mu mnich $\mathrm{w}$ geście adoracji ${ }^{30}$ zdają się eksponować sam doniosły akt ofiarowania, nie fragment liturgii. Niewykluczone, że kielich mógł w tym wypadku stanowić swoiste pars pro toto nowo wznoszonego kościoła. Budynek świątyni był w średniowiecznych formularzach poświęcenia kościoła nazywany sacramentum (Sczaniecki 19) ${ }^{31}$, co rodzi skojarzenia z namaszczonymi krzyżmem sakramentaliami - kielichem i pateną.

Jeśli zgodzimy się z wypowiedziami tych badaczy, którzy pojmują obraz jako zjawisko wytwarzające sens w sobie tylko właściwy sposób (dostępny jedynie wizualnie), a nie jako pośrednika przekazującego istniejące już w medium słowa „znaczenie do rozszyfrowania” i że dzieło jest rodzajem gry, wciągającym widza w niekończące się poszukiwanie ${ }^{32}$, to łatwiej będzie nam dostrzec tkwiący $w$ tych przedstawieniach spory potencjał możliwych skojarzeń. Być może zamysł przedstawienia fundatora nie tradycyjnie, z modelem kościoła, który nadawałby tej scenie jednoznaczną wymowę, a z kielichem eucharystycznym, był obliczony właśnie na zwielokrotnienie sensu przedstawienia (Baschet 53). Poniekąd sprzyja temu także brak inskrypcji, która zapewne narzucałaby dominację jednego sposobu odczytu. Chwałę

${ }^{28}$ „W Niemczech XI-XII wieku często fundatora miano za świętego, a nierzadko otaczano go kultem religijnym. Aby zdać sobie sprawę z rozmiarów tego zjawiska, podamy, jedynie tytułem przykładu, kilka takich wypadków wyłącznie z obszaru dawnej diecezji (nie: prowincji) kolońskiej...”.

${ }^{29}$ Ratkowska, analizując późnoromańską miniaturę (powstała po 1203 r.) przedstawiającą magistra Gislebertusa Porretanusa, biskupa Pictaviensis, kanclerza szkoły w Chartres, z uczniami - wszystkich wyobrażono z nimbami - określiła to jako przykład uznania dla autorytetu uczonego biskupa w średniowieczu. Może i w przypadku Odrowąża miał znaczenie jego status uczonego teologa; Kalinowski sugerował, że to dowód uznania dla zmarłego biskupa: Kalinowski 117.

${ }^{30}$ Nie jest to gest względem biskupa, jak sądziła Hewner, nazywając go „gestem posłuszeństwa” (zob. „Tympanon w Wysocicach” 119).

${ }^{31} \mathrm{~W}$ przyp. 6 ks. Sczaniecki przytacza cytat $\mathrm{z}$ Graduału: ,Locus iste est inaestimable sacramentum"

${ }^{32}$ Literatura odnosząca się do tych zagadnień jest nader obfita; mam na myśli zwłaszcza wypowiedzi Arnheima, Francastela czy hermeneutycznie zorientowanych badaczy historii sztuki. W odniesieniu do sztuki średniowiecznej podobnie widzi ten problem Baschet 53-54. 
Jezusa i wybawienie od śmierci wiecznej sprawiedliwego, używając metafory kielicha, zapowiadał autor Psalmu 16: „Jahwe, jesteś całym bogactwem i kielichem moim (...) dasz mi poznać drogę do życia, do pełni radości przed Twoim obliczem i do rozkoszy po prawicy Twojej na zawsze" (Księga Psalmów 145-150) ${ }^{33}$; nadzieja na zbawienie łączy się w tym przypadku z nadzieją na zbawcze skutki aktu fundacji. Wyobrażenie biskupa eksponującego kielich może być jednocześnie wskazaniem na trzeci - obok Słowa Przedwiecznego i Wcielonego - bo eucharystyczny „sposób” obecności Chrystusa. W kontekście przedstawień Chrystusa-Sędziego i Bożego NarodzeniaWcielenia osoby wyobrażone po prawej stronie Chrystusa reprezentowałyby czas od chwalebnej śmierci i Zmartwychwstania po Powtórne Przyjście Słowa, zgodnie ze słowami św. Pawła: „Ilekroć bowiem [...] kielich pijecie, śmierć Pana głosicie, aż przyjdzie" (1 Kor 1,26). Takie skojarzenie pozwala odczytywać całość jako obraz dziejów zbawienia: w centrum - panujący poza czasem, hieratyczny Chrystus Tronujący, Emmanuel, Słowo Przedwieczne, jako początek i koniec dziejów. Po jednej stronie: Wcielenie uosabiające czas ziemskiej działalności Słowa, po drugiej: następujący po niej czas działania Kościoła (Eucharystii). Nie kłóci się to z tematem unii hipostatycznej, raczej go dopełnia; zawartość kielicha eucharystycznego - wino (oznaczające bóstwo Chrystusa) zmieszane $\mathrm{z}$ wodą (oznaczającą jego człowieczeństwo) już w średniowieczu uznawano za symbol połączenia ze sobą dwóch natur Jezusa, co wyrażała modlitwa wypowiadana przy dolewaniu wody do wina $\mathrm{w}$ trakcie mszy ${ }^{34}$. W takim rozumieniu oba przedstawienia po prawej i lewej stronie Chrystusa Tronującego byłyby w swoisty sposób względem siebie symetryczne, obrazując na dwa różne sposoby (co sygnalizuje już ich odmienna wizualna struktura) prawdę o zjednoczeniu dwóch natur w Chrystusie.

Nie jest więc to dzieło „naśladowcze” i wtórne; operuje jedynie podobnymi do strzelneńskiego motywami, ale użyte są tu w pełni świadomie, tworząc inny obrazowy przekaz. Wiele przemawia wręcz za tym, że tympanon wysocicki był w zakresie semantyki wspieranej adekwatnymi środkami artystycznymi, pomysłem indywidualnym, oferującym odbiorcom o różnych doświadczeniach wizualnych i różnym przygotowaniu teologicznym, dawniej i dziś, możliwości odczytu na różnych poziomach interpretacyjnych.

${ }^{33}$ Kielich jest tu objaśniony jako metafora losu (kielich zbawienia lub gniewu Bożego).

${ }^{34}$ Modlitwa pochodząca zapewne z sakramentarza gregoriańskiego (Nowowiejski 708, 714715). Fragment tejże modlitwy: „(..) spraw przez tajemnicę wody i wina, abyśmy stali się uczestnikami bóstwa tego, który raczył stać się uczestnikiem naszego człowieczeństwa (...)”. 


\section{BIBLIOGRAFIA}

Arnheim, Rudolf. Sztuka i percepcja wzrokowa. Psychologia twórczego oka. Tłum. Jolanta Mach, Słowo/obraz terytoria, 2004

Baschet, Jérome. „Inwencyjność i seryjność średniowiecznych przedstawień wizualnych. W kierunku poszerzonej metody badania ikonografii”. Polska Sztuka Ludowa. Konteksty. Antropologia kultury, etnografia, sztuka, t. 59, nr 3, 2005, ss. 49-70.

Berliner, Rudolf. „The Freedom of Medieval Art”. Gazette des Beaux-Arts, seria 6, nr 28, 1945 , ss. 263-288.

Boerner, Bruno. Bildwirkungen. Die kommunikative Funktion mittelalterlichen Skulpturen. Reimer Verlag, 2008.

Bracha, Krzysztof. „Magia słowa. Świadectwa teologów i wierzenia popularne w XV w.” Kwartalnik Historyczny, t. 98, nr 3, 1991, ss. 17-32.

Chrzanowski, Tadeusz, i Marian Kornecki. Sztuka Ziemi Krakowskiej. Wydawnictwo Literackie, 1982

Dobrowolski, Tadeusz, „Posąg Matki Boskiej w Wysocicach, przyczynek do dziejów rzeźby romańskiej w Polsce". Folia Historiae Artium, t. 10, 1974, ss. 37- 49.

Dobrowolski, Tadeusz. „Kościół św. Mikołaja w Wysocicach”. Sprawozdania z czynności i posiedzeń Polskiej Akademii Umiejętności, t. 28, 1923, ss. 8-11.

Dobrowolski, Tadeusz. „Kościół św. Mikołaja w Wysocicach”. Studia do Dziejów Sztuki w Polsce, t. 4, 1931, ss. 11- 46.

Dobrzeniecki, Tadeusz. „Maiestas Domini w zabytkach polskich i obcych z Polską związanych (cz. 3)", Rocznik Muzeum Narodowego w Warszawie, t. 19, 1975, ss. 5-263.

Dobrzeniecki, Tadeusz. „Romański posążek Madonny z Dzieciątkiem w Muzeum Narodowym w Warszawie". Rocznik Muzeum Narodowego w Warszawie, t. 10, 1966, ss. 109-164.

Evdokimov, Paul. Sztuka ikony. Teologia piękna. Tłum. Maria Żurowska, Wydawnictwo Księży Marianów PROMIC, 1999.

Furmankiewiczówna, Kazimiera, „Rzeźby romańskie z Goźlic”. Sprawozdania z posiedzeń Komisji Historji Sztuki za czas od 1 I. 1923 - do 31.XII 1925. Prace Komisji Historii Sztuki, t. 4, 1930, ss. 19-20.

Hewner, Katarzyna, „Próba identyfikacji wczesnośredniowiecznego warsztatu budowlanego ze Strzelna”. Nasza Przeszłość, t. 99, 1999, ss. 5-46.

Hewner, Katarzyna, „Tympanon w Wysocicach: próba interpretacji ikonologicznej”. Saeculum Christianum: pismo historyczno-spoteczne, $\mathrm{nr}$ 15/2,2008, ss.109-125.

Hewner, Katarzyna. „Romański tympanon z Wysocic”. Teki Krakowskie, nr 12, 2000, ss. 105-114.

Kalinowski, Rafał. „Wysocice, nowe spojrzenie. Komunikat”. III Forum Architecturae Poloniae Medievalis, t. I, red. Klaudia Stala, Instytut Historii Architektury i Konserwacji Zabytków Wydziału Architektury Politechniki Krakowskiej, 2013, ss. 105-130.

Kemp, Wolfgang. Christliche Kunst. Ihre Anfänge. Ihre Strukturen. Schirmer/Mosel Verlag, 1994.

Klawek, Antoni. „Zmiany liturgiczne w świetle historii”. Ruch Biblijny i Liturgiczny, t. 5, 1965, ss. 273-279.

Kopera, Feliks. „Rzeźba do wieku XIII włącznie”. Polska, jej dzieje i kultura. t. 1, red. Stanisław Lam, Nakładem Trzaski, Everta, Michalskiego, 1927, ss. 414- 418. 
Księga Psalmów. Wstęp - przekład z oryginatu-komentarz-ekskursy, oprac. Stanisław Łach, Pallottinum, 1990 .

Łuszczkiewicz, Władysław. Zabytki dawnego budownictwa w Krakowskiem [w obrębie zarzadu c.k. Konserwatora krakowskiego]. nakł. P. Popiela, Kraków, 1868.

Michałowski, Roman. „Święta moc fundatora klasztoru (Niemcy XI-XII wieku)”. Kwartalnik Historyczny, t. 91, nr 1, 1984, ss. 3-24.

Mroczko, Teresa. Polska sztuka przedromańska i romańska. Wydawnictwa Artystyczne i Filmowe, 1978.

Mrozowski, Przemysław, „Polskie tablice erekcyjne z wieków XIV i XV”. Studia Źródłoznawcze, nr 32/33, 1990, ss. 77-112.

Mrozowski, Przemysław., „Gotyckie tablice erekcyjne i romańskie tympanony fundacyjne jako wyraz odmiennej sytuacji prawnej fundatorów”. Mecenas, kolekcjoner, odbiorca. Materiaty Sesji SHS, Katowice 1981, red. Elżbieta Karwowska i Anna Marczak-Krupa, PWN 1984, ss. 55- 62.

Nowowiejski, Antoni J. Msza Święta. Cz. 1, Wydawnictwo Antyk Marcin Dybowski, 2001. (Płockie Wydawnictwo Diecezjalne 1993).

Quirini-Popławski, Rafał. Rzeźba przedromańska i romańska w Polsce wobec sztuki włoskiej. Wydawnictwo Uniwersytetu Jagiellońskiego, 2006.

Ratkowska, Paulina. „'Iluminatio a pura sapientia'. Uwagi o miniaturze Ms 197 w Bibliothèque Municipale w Valenciennes”. Biuletyn Historii Sztuki, t. 30, nr 3, 1968, ss. 337-345.

Schwarz, Mario. Die Baukunst des 13. Jahrhunderts in Österreich. Böhlau Verlag, 2013.

Sczaniecki, Paweł. „Sacramentum dedicationis”. Studia Kościelno-Historyczne, t. 3, 1979, ss. 1-137.

Soćko, Adam. „Strzelneński zespół klasztorny w perspektywie rodowych fundacji margrabiów von Wettin. Rzeźba-architektura-historia”. Nasza Przeszłość, t. 98, 2002, ss. 99-161.

Starzyński, Juliusz, i Michał Walicki. Dzieje sztuki Polskiej. M. Arct, 1934.

Świechowski, Zygmunt. „Studia nad rzeźbą w Strzelnie”. Rocznik Historii Sztuki, t. 8, 1970, ss. 71-116.

Świechowski, Zygmunt. „Znaczenie najnowszego odkrycia w Strzelnie”. Ochrona Zabytków, t. 7, 1954, ss. 273-276.

Świechowski, Zygmunt. Budownictwo romańskie w Polsce. Katalog zabytków. Ossolineum, 1963

Świechowski, Zygmunt. Katalog architektury romańskiej w Polsce. DiG, 2009

Thome, Marcus. Kirche und Klosteranlage der Zisterzienserabtei Heiligenkreuz. Die Bauteile des 12. und 13. Jahrhunderts. Imhof Verlag, 2007.

Walczak, Marek. Rzeźba architektoniczna w Małopolsce za czasów Kazimierza Wielkiego. Universitas, 2006.

Walicki, Michał. „Dekoracja architektury i jej wystrój artystyczny”. Sztuka polska przedromańska i romańska, red. Michał Walicki, PWN 1971, ss. 197-248.

Wirth, Jean. L'image médiévale. Naissance et développement (VI $-X V^{e}$ siècles). Méridiens Klincksieck, 1989.

Worm, Andrea. „Das illuminierte Wort. Bilderprogramme und Erzählstrukturen historiesierten Initialen zur Genesis". Mittelalterliche Weltdeutung in Text und Bild, hrsg. Susanne Ehrich i Julia Ricker, VDG Verlag und Datenbank für Geisteswissenschaften, 2008, ss. 99-132. 


\title{
ROMAŃSKI TYMPANON \\ KOŚCIOŁA PARAFIALNEGO W WYSOCICACH. GŁOS W DYSKUSJI
}

\begin{abstract}
Streszczenie
Artykuł polemizuje z niektórymi dotychczasowymi tezami i stanowi uzupełnienie poruszanych wcześniej zagadnień. Tympanon niesłusznie ma opinię prymitywnie wykonanego. Jest nieukończony, ale partie w pełni opracowane noszą znamiona ręki wprawnego artysty. Przypisanie go do warsztatu pracującego w Strzelnie jest właściwe (ale nie jako naśladownictwo), lecz wskazanie na pośredni wpływ mistrza Wiligelma czy włoski warsztat w Heiligenkreuz - nietrafne. Nie jest też bezpośrednio zależny od alzackich, nadreńskich czy saskich przykładów, jest raczej (tak jak i ten w Strzelnie) zjawiskiem „,równoległym” do nich. Tympanon upamiętnia i dopełnia akt fundacji bpa Odrowąża, prezentuje prawdy teologiczne, jak i odwołuje się do dziejów zbawienia. Wykorzystano do ich prezentacji przedstawienia, które towarzyszyły tekstom Prologu ewangelii według św. Jana (Maiestas Domini i Boże Narodzenie), a jednocześnie unaoczniały dogmat o unii hipostatycznej dwóch natur Chrystusa. Fundator trzymający w dłoniach kielich eucharystyczny ukazuje obecność Chrystusa pod postacią Sakramentu Eucharystii. Pozwala to rozumieć sens całości „dogmatycznie” i „historycznie” - jako dzieje Zbawienia (Słowo Przedwieczne, Wcielenie, czas Kościoła = Eucharystia - po powtórne przyjście Chrystusa).
\end{abstract}

Słowa kluczowe: tympanon; kościół w Wysocicach; rzeźba romańska w Polsce; ikonografia; unia hipostatyczna w sztuce; fundacje Iwo Odrowąża.

\section{THE ROMANESQUE TYMPANUM OF THE PARISH CHURCH IN WYSOCICE: ANOTHER OPINION IN THE DEBATE}

\section{Su m mary}

This article challenges some of the previously-held opinions and is itself a supplement to earlier issues. The tympanum has been wrongly supposed to have been crudely wrought. It is incomplete, but there are some fragments which show the work of a skillful artist. It has actually been attributed to the oeuvre of a workshop operating in Strzelno (but not as an imitation) and has been inaccurately stated to have been influenced by the sculptures of Master Wiligelm and the Italian workshop operating in Heiligenkreuz. It is, rather, a work "parallel to" those examples from Alsace, the Rheinland and Saxony. The tympanum from Strzelno both commemorates and complements the foundation of the church by Bishop Odrowąż, and shows theological truths and the history of Salvation according to the "Prologue" of Saint John (Maiestas Domini and the Nativity), whilst simultaneously visualising the dogma of the hypostatic union of the two natures of Christ. This allows us to understand the whole of the tympanum from both the "dogmatic" and "historical" perspectives as being the history of Salvation (with the founder holding the Eucharistic chalice, reminding us of Christ's presence in the sacrament of the Eucharist).

Keywords: tympanum; church in Wysocice; Romanesque sculpture in Poland; iconography; hypostatic union in art; church foundings by Iwo Odrowąż. 


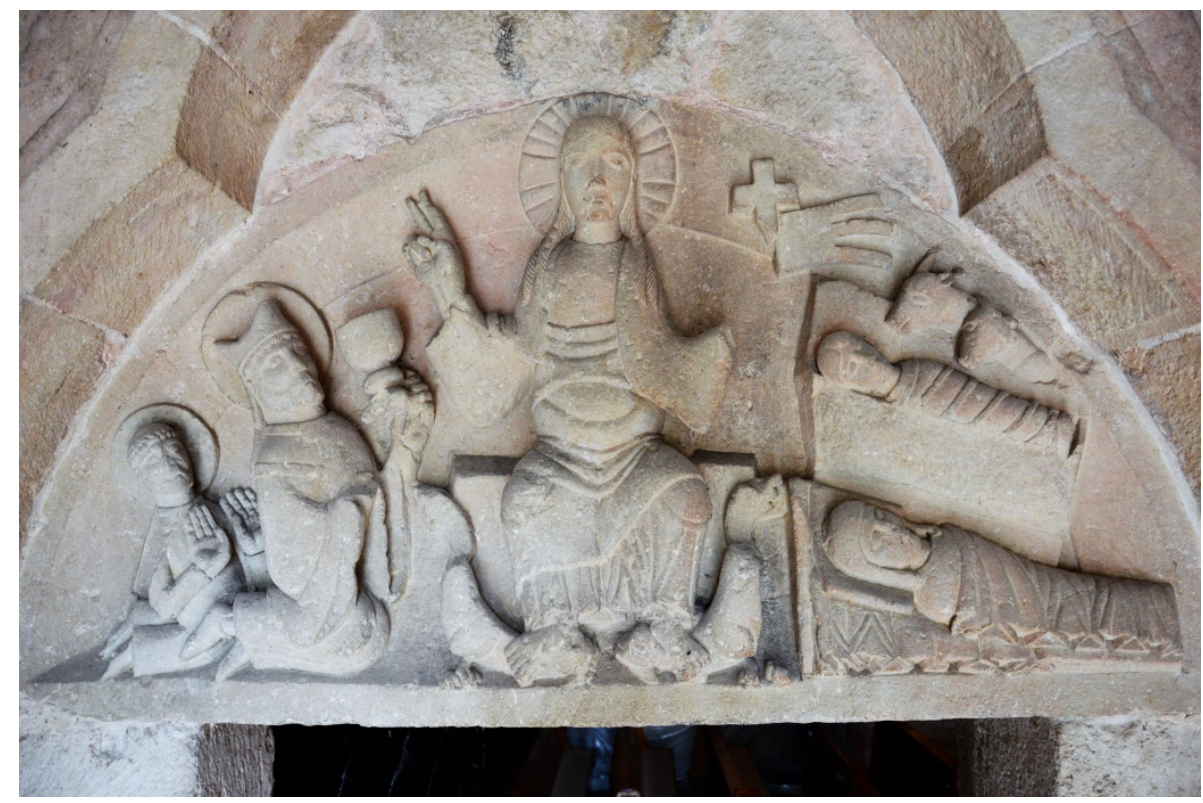

1. Tympanon portalu kościoła parafialnego w Wysocicach, ok. 1220-1230 r., fot. Anna Błażejewska

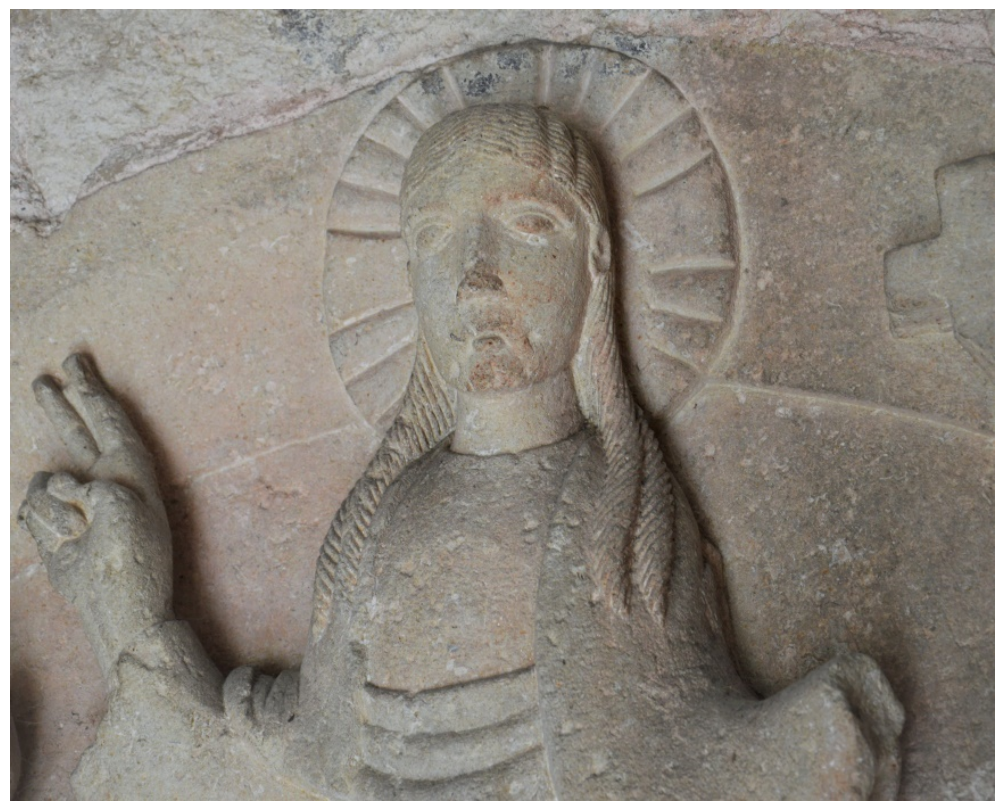

2. Maria Tronująca z Dzieciątkiem, wschodnia ściana korpusu kościoła parafialnego w Wysocicach, ok. 1220-1230 r., fot. Anna Błażejewska 


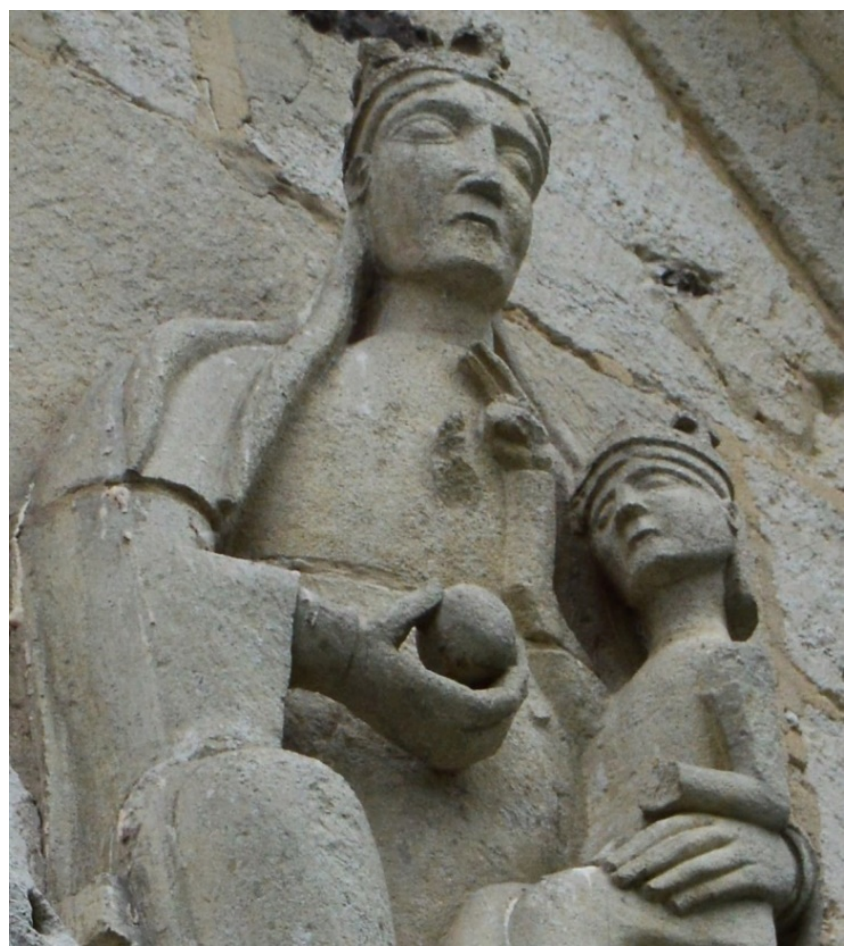

3. Chrystus Tronujący, tympanon kościoła parafialnego w Wysocicach, ok. 1220-1230 r., fot. Anna Błażejewska

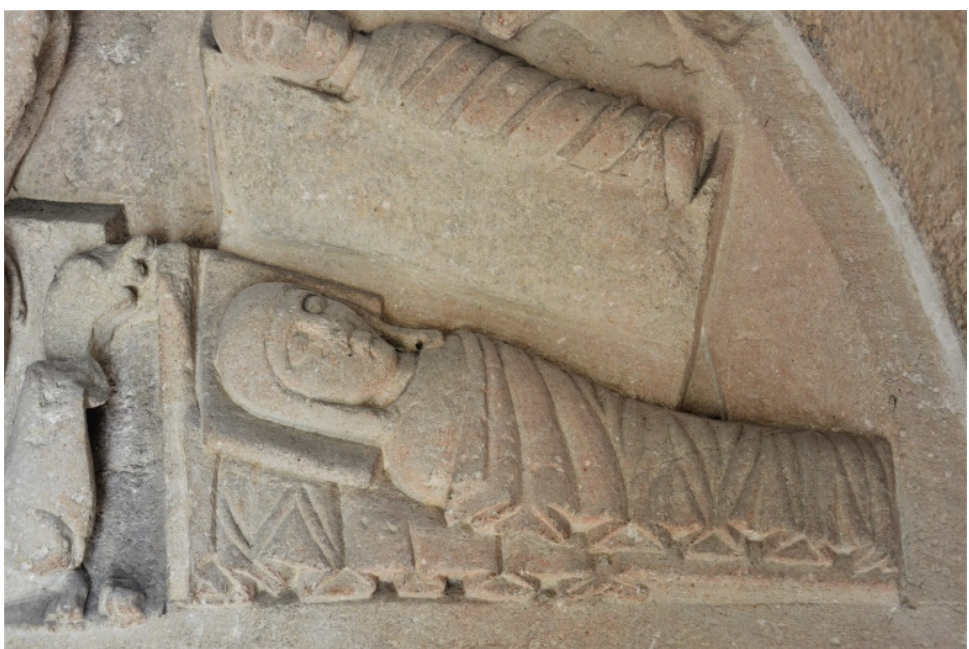

4. Maria ze sceny Bożego Narodzenia, tympanon kościoła parafialnego w Wysocicach, ok. 1220-1230 r., fot. Anna Błażejewska 


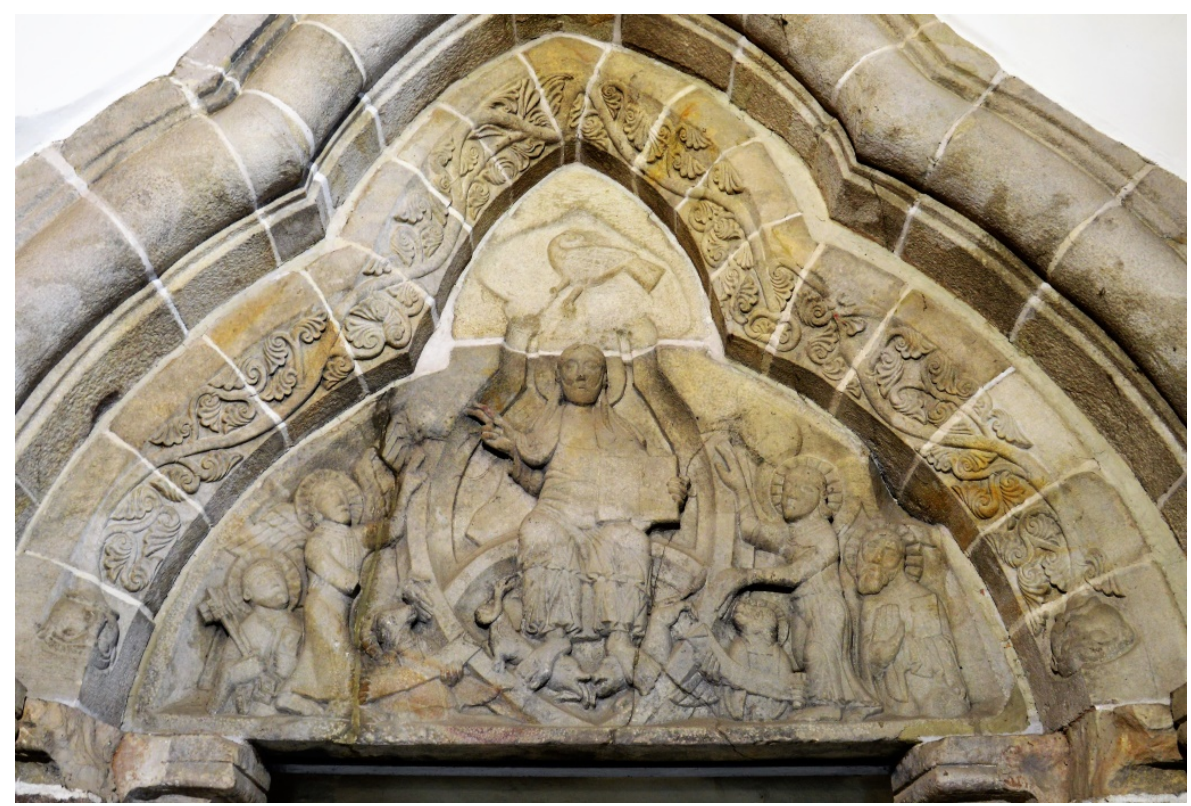

5. Tympanon północny kościoła norbertanek w Strzelnie, 1 ćwierć XIII wieku, fot. Anna Błażejewska.

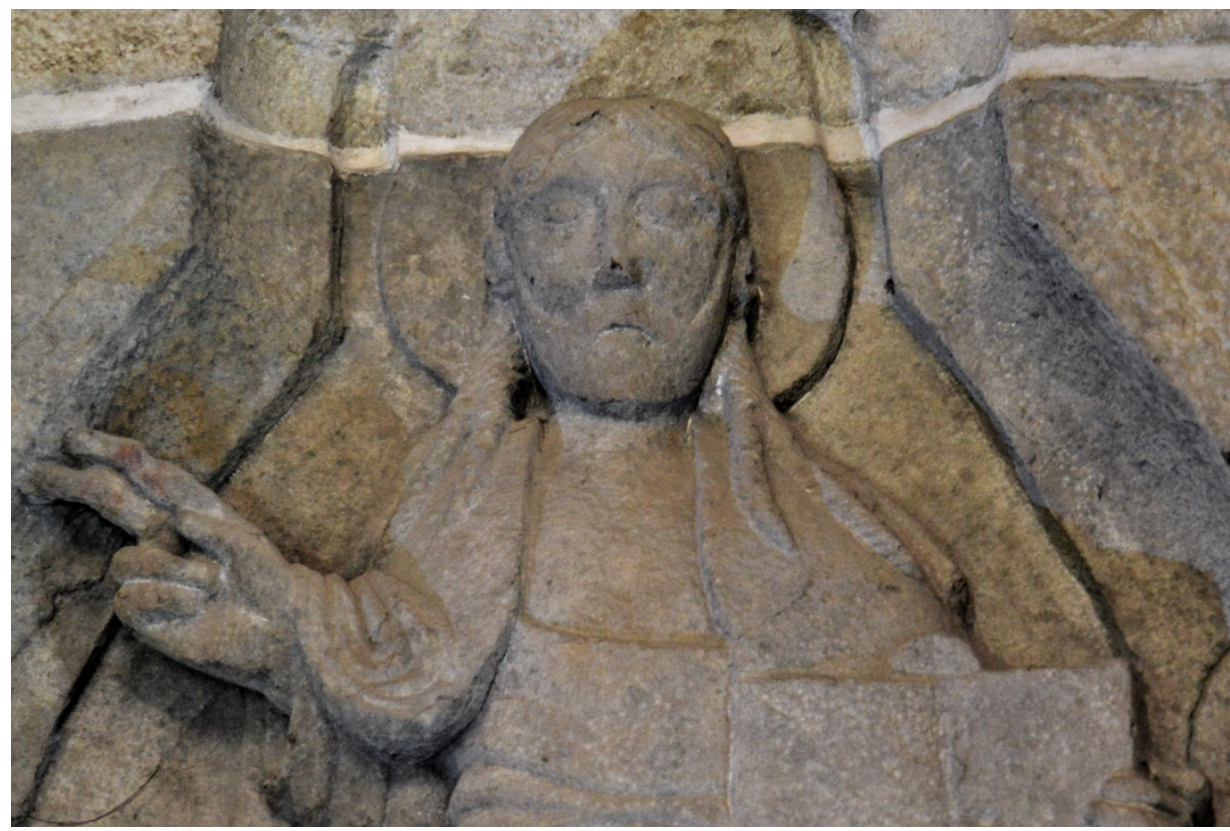

6. Chrystus w Majestacie, tympanon północny kościoła norbertanek w Strzelnie, 1 ćwierć XIII wieku, fot. Anna Błażejewska 


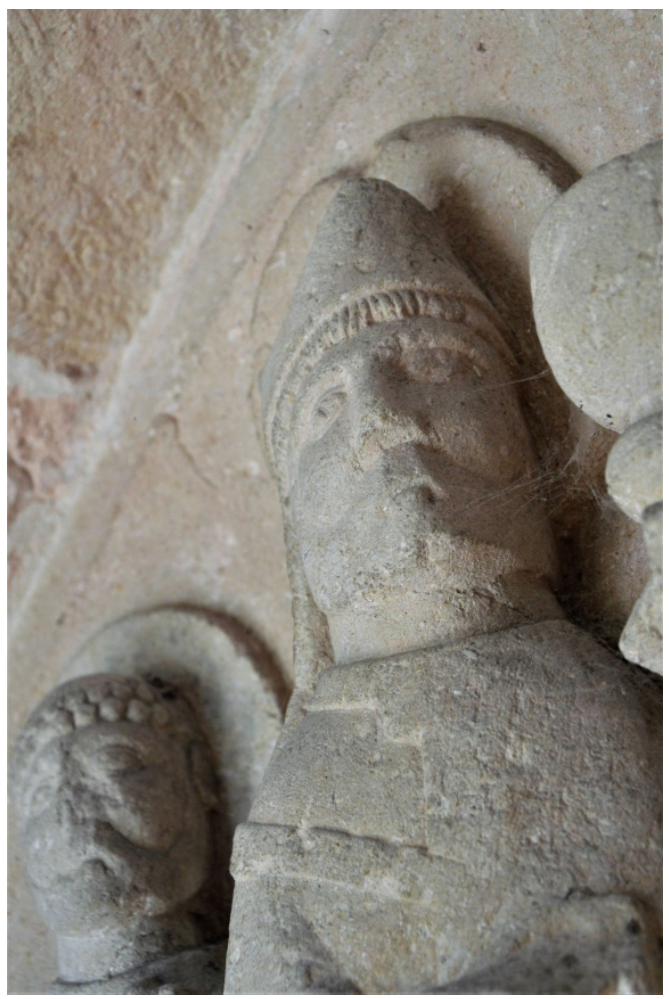

7. Klęczące postaci duchownych, tympanon kościoła parafialnego w Wysocicach, ok. 1220-1230 r. , fot. Anna Błażejewska

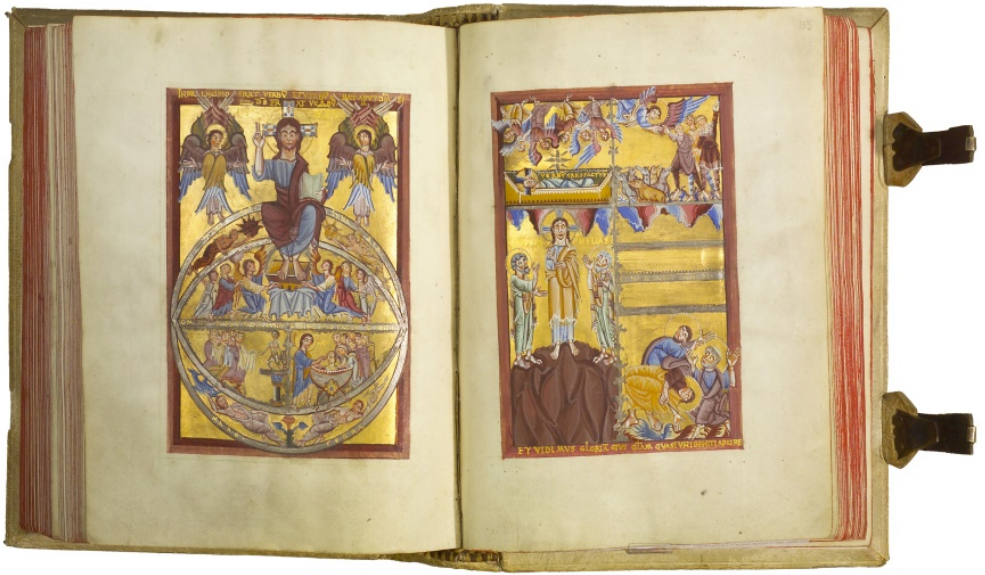

8. Prolog Ewangelii św. Jana, Ewangeliarz katedry w Bambergu, Staatsblibliothek, Msc.Bibl.94, s. 154v, 155r, ok. 1050 r.

za: images.eo-bamberg.de/1/5/8/35264914754736786209.jpg, dostęp 8.05.2019 